\title{
Apel na sobeckost nebo na rozumnost? Prípadová analýza s využitím Toulminova modelu argumentu ${ }^{1}$
}

\author{
Tomáš Ondráček \\ Katedra podnikového hospodářství \\ Masarykova univerzita \\ Lipová 507/41a, 60200 Brno \\ ondracek.t@mail.muni.cz
}

Př́spěvek se zaobírá Toulminovým přístupem k argumentaci. Hlavním cílem je přitom představit tento př́stup a ukázat jeho aplikaci na vybraném materiálu. Klíčová otázka poté zní: $\mathrm{V}$ čem je Toulminův přistup stále aktuální a co může při zkoumání argumentů přinést? Cúle i odpovědi na otázku je dosahováno ve dvou základních krocích. V prvním kroku je probrána teorie argumentu, jak ji Toulmin prezentuje především ve své knize The Uses of Argument. Ve druhém kroku je pak Toulminův př́stup aplikován na vybraný materiál, konkrétně na videospot Přemluv bábu (2010). Pozornost je přitom věnována zejména modelu argumentu, doménové závislosti, logickým typům a druhům argumentu. V př́spěvku je nakonec ukázáno, že Toulmin je stále diskutovaný a teoreticky podnětný, a také to, že jeho aplikace na vybraný materiál může poskytnout dobrá vodítka pro hodnocení tohoto materiálu i v př́padech, kdy toto hodnocení není možné udělat jednoznačně pomocí formálních nástrojů.

Klíčová slova: Toulmin, S. E., Toulminův model argumentu, argument, logický typ, Přemluv bábu

1 Práce na této stati byla podpořena Grantovou akademií České republiky (GAČR), grant „Sémantické pojmy, paradoxy a hyperintenzionální logika založená na moderní rozvětvené teorii typü“, reg. č. GA16-19395S. 


\section{Úvod}

V roce 1958 vyšla kniha The Uses of Argument od Stephena Edelstona Toulmina. ${ }^{2}$ I když se nejedná o jeho první práci, ve které se věnuje teorii argumentů, ${ }^{3}$ jedná se o jeho první dílo, které je zcela zaměřené na tuto problematiku. ${ }^{4}$ Toulmin se $\mathrm{v}$ této knize jasně vymezuje proti formálnímu přístupu $\mathrm{k}$ argumentům a jeho pokládání za ideál a arbitr racionality.

Toulminova kniha po svém vydání vzbudila nejednoznačné reakce. Byla odmítána až zatracována. ${ }^{5}$ Toulminovi bylo vytýkáno, že jeho kritika logiky a formálního přístupu je neadekvátní a vlastní návrh vágní a chybný. ${ }^{6}$ Bylo poukazováno na to, že se ve svém př́ístupu vrací ke středověkým teoriím a Aristotelovi.7 Na druhé straně byla Toulminova práce ceněna pro své zaměření na užívání argumentů $\mathrm{v}$ praxi $^{8} \mathrm{a}$ jeho přístup byl využíván $\mathrm{k}$ výuce argumentace $\mathrm{v}$ rámci oborů zaměřujících se na komunikaci. ${ }^{9}$ Pozitivní hodnocení s ohledem na možnost uchopení běžných, skutečných argumentů nakonec převážilo některé teoretické problémy a Toulminova kniha je dnes považována za jednu ze základních knih v teorii argumentace. ${ }^{10}$

Cílem této práce je stručně představit hlavní prvky Toulminova přístupu $\mathrm{k}$ argumentu a ukázat jeho praktické použití při analýze vybraného materiálu Přemluv bábu. ${ }^{11}$ Tato analýza by přitom měla ilustrovat některá

2 V této práci je využívána aktualizovaná edice knihy z roku 2003, viz Toulmin (2003).

3 Toulmin se argumentům i jejich struktuře věnoval už např. v An Examination Of The Place of Reason in Ethics (Toulmin 1953a, nap̌̌. s. 27-28, 39), i když zde se zaměřoval především na etiku. Pro přehled Toulminových publikací viz O’Hara (2006).

4 Později se k problematice argumentů ještě vyjadřuje v dalších dílech. Např. ve společné knize An Introduction to Reasoning (Toulmin, Rieke \& Janik 1984), která má sloužit jako učebnice pro kritické myšlení a argumentaci, znovu předkládá svůj přístup, byt’ s drobnými změnami a zjednodušeními.

5 Toulmin (2003, s. viii) v předmluvě k aktualizované verzi popisuje, že jeho kniha byla anglickými profesionálními filosofy po dlouhé roky ignorována poté, co ji Peter Strawson zatratil v pořadu BBC.

6 Srovnej Cooley (1959), Castaneda (1960), Abelson (1961), Cowan (1964).

7 Bird (1961).

8 Brockriede \& Ehninger (1960).

9 Srovnej Kneupper (1978), Karbach (1987).

10 Srovnej Hitchcock \& Verheij (2005), Hitchcock \& Verheij (2006), van Eemeren et al. (2014).

11 Issová, Mádl \& Zelenka (2010). 
silná a slabá místa tohoto př́stupu a následně dokladovat, že je stále plodným a zajímavým. Aby bylo možné naplnit tyto cíle, je první část věnována východiskům Toulminova př́stupu (1. Argument a doménová závislost). Ve druhé části je představen model argumentu a jeho složky (2. Model argumentu). Třetí část je zaměřena na problematiku typů argumentů (3. Typy argumentů). Následující aplikační část je pak věnována analýze vybraného materiálu Přemluv bábu (4. Analýza).

\section{Argument a doménová závislost}

\subsection{A rgument a zdůvodnění}

Primární funkcí argumentu je zdůvodnění nebo obhajoba předložených stanovisek (stanovisko, claim). ${ }^{12}$ Všechny ostatní možné funkce jsou podle Toulmina odvozené. ${ }^{13} \mathrm{Za}$ argument lze obecně považovat strukturu obsahující stanovisko a důvody pro toto stanovisko, tedy strukturu, ve které jsou minimálně dvě tvrzení, kdy jedno tvrzení podporuje přijatelnost druhého tvrzení, stanoviska. I když by se mohlo zdát, že Toulmin označuje místy za argument pouze premisy, důvody, východiska apod., nezdá se, že by takový pohled odpovídal tomu, jak obecně s argumenty pracuje. Pokud Toulmin píše o argumentu, ukazuje jej ve smyslu předkládání podpory pro nějaké stanovisko.

To odpovídái druhé charakteristice argumentů, totižjejich procesnímu určení. ${ }^{14}$ Předkládání důvodů, tedy vytváření struktury argumentu, je chápáno jako proces odpovídání na otázky, pochyby, kritiku. Argumenty jsou budovány, nikoli dány. Jejich vytváření je pak ovlivněno prostředím, ve kterém se vyskytují.

12 Van Eemeren et al. (2014, s. 14) poukazuje např. na to, že Toulmin zavedl do teorie argumentace pojem claim, který je stále užíván. Protože claim je chápáno jako referující k pojmu standpoint a zároveň pro každý objekt označovaný jako claim platí, že je také možné jej označit jako assertion, ale nikoli vice versa, budu z nedostatku vhodné české terminologie překládat slovo „claim“ jako „stanovisko“ a „assertion“ jako „tvrzení“. Jiné možnosti se nezdají př́liš vhodné. Např́íklad pojem teze je spojen spíše s Aristotelovým pojetím argumentace a evokuje formálnější přistup k dialektice. V textu tak bude slovo „stanovisko“ označovat Toulminův koncept označený slovem „claim“. Pokud tomu bude jinak, bude na to čtenář upozorněn.

13 Toulmin (2003, s. 12).

14 Srovnej např. tamtéž, s. 17. 
Toto pojetí argumentu souvisí následně i se zdůvodněním (justification). Zdůvodnění není u Toulmina dáno jako něco, co je vlastní určitému tvrzení. Není tomu tedy tak, že jednotlivé tvrzení je schopné dát důvody pro nějaké stanovisko a že tyto důvody jsou inherentní onomu prvnímu tvrzení. ${ }^{15}$ Zdůvodnění je dáno vztahem mezi alespoň dvěma tvrzeními v daném kontextu. ${ }^{16}$ Jedná se o proces předkládání důvodů, které jsou pro danou situaci príjatelné. Takovéto pojetí zdůvodnění je odlišné od toho, které bylo podle Toulmina zastáváno ve formálních př́stupech $\mathrm{k}$ argumentům a logice.

\subsection{Logika a platnost}

V odkazu na Aristotela poukazuje Toulmin na dvojí úkol logiky: porozumět tomu, jak se tvoří závěry (apodeixis), a ustavit vědu o tom, jak se závěry tvoří (epistémé). ${ }^{17}$ Toulmin tvrdí, že logika se postupně začala zaobírat spíše formální stránkou, vědou, a zapomněla na praxi. Jak ale „může logika doufat v to, že je formální vědou a zároveň si udržet schopnost aplikace při kritickém posuzování skutečných argumentư"? ${ }^{18}$ Pokud totiž budeme při hodnocení argumentů přihližet pouze k formální stránce, pak mnoho argumentů z praxe nebude formálně adekvátních. Logika podle Toulmina ztratila ze zřetele první cíl, totiž porozumění, nebot’ zapomněla na to, že argumenty v praxi jsou předkládány v určitém kontextu, který zajištuje vztah podpory.

Logický př́stup $\mathrm{k}$ argumentům je podle Toulmina patrný v pojetí platnosti (validity) argumentů. Platnost je ve formálním přístupu a logice identická s formální platností. ${ }^{19}$ Toulmin v tomto ohledu mluví ogeometrickém, ${ }^{20}$ později dokonce o kvazi-geometrickém pojetívalidity. ${ }^{21}$

15 Jedná se vlastně o emergentní pojetí zdůvodnění, jak jej prezentuje např. Aikin (2010, část 3.1) v souvislosti s infinitismem.

16 Srovnej Toulmin (2003, s. 16-17).

17 Toulmin (2003, s. 2) se odvolává na první větu z Prvních analytik (Aristotelés 1961, s. 27): „Nejprve je třeba pojednat o tom, čeho se zkoumání týká a čí je to úkol; týká se důkazu a je to úkol dokazovací vědy.“ Nicméně Toulminova interpretace této věty je sporná, viz např. van Eemeren et al. (2014, s. 206).

18 V originále Toulmin (2003, s. 3): „how far logic can hope to be a formal science, and yet retain the possibility of being applied in the critical assessment of actual arguments“.

19 Toulmin (2003, s. 88).

20 Např. tamtéž, s. 132, 136, 164-168, 229-230.

21 Např. Toulmin (1976, s. 93, 125, 135). 
Pokud jsou přijata východiska argumentu, pak hodnocení spočívá pouze v hodnocení formy. Jinými slovy lze říci, že závěr argumentu je obsažen v jeho premisách. Toulmin ilustruje logické pojetí platnosti na hodnocení sylogismů. ${ }^{22}$ Vezměme následující př́klad (př. 1.):

P1:Všichni sportovci jsou lidé.

P2:Všichni lidé jsou smrtelní.

Z: Všichni sportovci jsou smrtelní.

Jedná se o tradiční sylogismus modu BARBARA. Máme zde tři univerzální kladná tvrzení. $\mathrm{K}$ analýze sylogismů, ke zjištění jejich platnosti, je běžně užíváno různých formálních nástrojů. Sylogismy je možné přepsat pomocí klasické predikátové logiky, případně zakreslit $\mathrm{s}$ využitím Vennových diagramů. Zde uvedený př́klad je možné zakreslit jako množinu sportovců, která je podmnožinou množiny lidí, kteří jsou podmnožinou množiny smrtelných (viz Schéma 1).

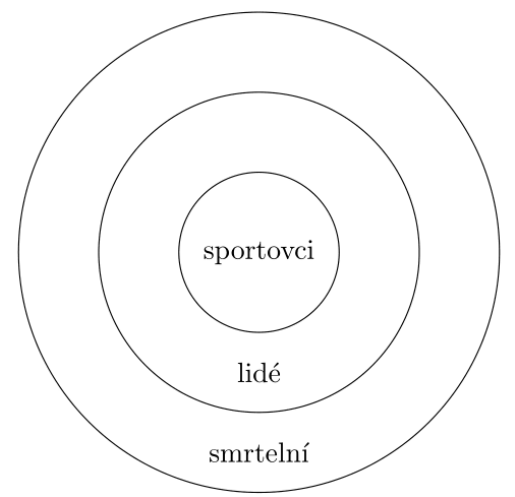

Schéma 1: Množiny

Pokud bychom využili přímo Vennovy diagramy ve formě tří překrývajících se kruhů, pak je možné postupně vyznačovat oblasti, ve kterých není možné, aby se vyskytovaly objekty, o kterých je řeč v daných tvrzeních. Jinými slovy je možné vyznačovat oblasti, které jsou prázdné. 
V uvedeném př́padě by tedy postup byl takový, že bychom nejprve označili jako prázdnou tu část oblasti sportovcủ, která není společná s oblastí lidí. Dále bychom vyznačili jako prázdnou tu část oblasti lidí, která není společná s oblastí smrtelných. Následně zbydou oblasti, ve kterých je možné, aby byly nějaké objekty. Poté lze ověřit, zda je možné, aby byly nějaké objekty $\mathrm{v}$ oblasti označující sportovce, která není společná oblasti smrtelných, tedy zda je možné, aby zde byli sportovci, kteří nejsou smrtelní (viz Schéma 2, kde šedou jsou vyznačeny prázdné oblasti a pomocí „X“ oblast závěru sylogismu).

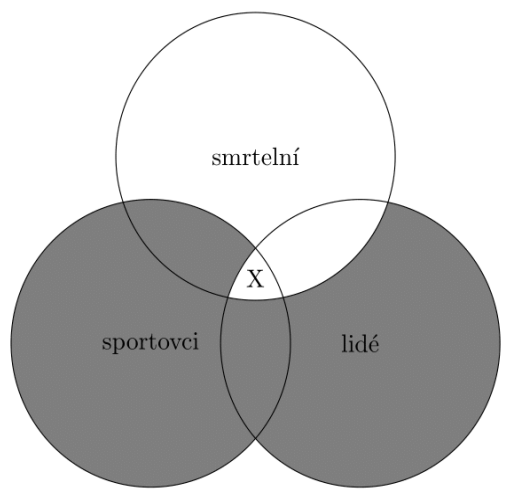

Schéma 2: Vennovy diagramy

Tento geometrický př́stup $\mathrm{k}$ validitě ale $\mathrm{v}$ konečném důsledku ukazuje, že pro určení platnosti, přijatelnosti, argumentu není v logice důležitý obsah, ale je důležitá pouze forma. Nicméně forma běžných argumentů tato kritéria často nesplňuje. Stačí upravit předchozí argument (př. 2.):

P1: Všichni sportovci jsou lidé.

P2': Všichni lidé, kteří doposud žili, byli smrtelní.

Z: Všichni sportovci jsou tedy smrtelní.

Jak zachytit pomocí Vennových diagramů druhé tvrzení (P2')? Jak je možné takovýto argument nakonec hodnotit? Logika, která se zaměřuje právě a především na formální aspekty, tak svou schopnost popisu praxe podle Toulmina ztrácí, nebo dokonce ztratila. Hodnocení argumentů v praxi je závislé na obsahu a na kontextu. Proti představě formální 
platnosti, dané geometrickou formou, proto Toulmin prezentuje konkurenční představu platnosti argumentu, totiž procedurální platnost, která je omezena doménou, ve které je argument předkládán. ${ }^{23}$

\subsection{Logické typy a doménová závislost}

Problém zachycení druhého prríkladu souvisí s problematikou tzv. logických typů (logical types). Logické typy nemají u Toulmina jasné vymezení. ${ }^{24}$ Je nicméně možné předpokládat, že navazoval na Russellovu teorii ${ }^{25}$ nebo na Ryla ${ }^{26}$. Logické typy v Toulminově práci je možné obecně pojímat jako označení skupiny jazykových objektů, pro které platí stejný proces hodnocení jejich užití. ${ }^{77,28}$

Toulmin představuje logické typy již ve své dřívější práci, $\mathrm{v} A n$ Examination of the Place of Reason in Ethics, ${ }^{29} \mathrm{kdy}$ rozlišuje mezi logickými, matematickými a faktuálními tvrzeními a tvrzeními o povinnostech nebo hodnotách. Nicméně je možné odlišit i další. Vezměme následující neúplný výčet ${ }^{30}$ :

1. Ministři předali svou rezignaci.

2. Probíhá hlasování o důvěře vládě.

3. V přištím roce proběhnou předčasné volby.

4. Obviněný se choval nevhodně.

5. Je těžké rozhodnout, kdo je odpovědný za krizi.

6. Nezvalovy rané básně jsou poetičtější než jeho pozdní tvorba.

23 Tamtéž, s. 235-236.

24 Srovnej O'Connor (1959, s. 244).

25 Srovnej Coquand (2018).

26 Van Eemeren et al. (2014, s. 213).

27 Použivám „hodnocení užiti““, abych jej odlišil od pravdivostní hodnoty a od přijatelnosti argumentu. Je možné zde spatřovat paralely i k Austinově (1962) teorii řečových aktů, se kterou Toulmin (srovnej 2003, s. 45-49) také pracuje. V Rylově koncepci je pak logický typ definován následovně, viz Ryle (2009, s. x): „The logical type or category to which a concept belongs is the set of ways in which it is logically legitimate to operate with it.“

28 Toulmin (1953b, s. 72) užívá logický typ také k odlišení mezi vlastním jménem a funkcí. I v tomto ohledu je možné říci, že rozlišení těchto pojmů je dané intuitivně odlišným procesem, který určuje jejich adekvátní užití.

29 Toulmin (1953a, s. 55, 114).

30 Srovnej van Eemeren et al. (2014, s. 214). 
7. Bude nutné přijmout opatření, aby se situace neopakovala.

Každé z těchto tvrzení může být pokládáno za spadající pod odlišný logický typ. První tři tvrzení jsou tvrzeními o faktech $\mathrm{v}$ minulosti (1.), v př́tomnosti (2.) a v budoucnosti (3.). Následující tvrzení jsou morálním (4.), kauzálním (5.) a estetickým (6.) soudem. Poslední tvrzení je návrhem akce (7.). U každého z těchto tvrzení, aby bylo zjištěno, zda je užito pravdivě nebo správně, musí proběhnout odlišný proces hodnocení. Zkoumání minulosti se liší od zjištování toho, co se zrovna děje, i předvídání toho, co nastane. Morální, kauzální i estetické souzení se odvolává na jiné standardy. Přijatelnost návrhu akce je pak založena na zcela odlišných kritériích než přijatelnost předchozích tvrzení.

Zatímco v prvním př́íladu (př. 1.) byly premisy postaveny na faktuálních tvrzeních, která měla univerzální povahu, ve druhém př́kladu (př. 2.) byla druhá premisa faktuálním tvrzením o minulosti. Zatímco v prvním př́íkladu byl závěr stejného logického typu jako premisy, ve druhém př́kladu odpovídal závěr pouze první premise. Druhý prŕklad proto představuje ukázku přechodu mezi typy, tzv. typový skok (type-jump)..$^{31}$ Proces hodnocení adekvátnosti užití druhé premisy a závěru je odlišný, a to způsobuje potíže pro geometrické pojetí platnosti. Nicméně rozdílné typy jsou v běžné argumentaci časté. Vezměme argument (př. 3.):

Tento projekt je dobrý, protože pomáhá lidem v nouzi.

V tomto argumentu je východiskem faktuální tvrzení a stanoviskem je hodnotové tvrzení. Tento přechod mezi faktuálním a hodnotovým tvrzením je z formálního hlediska pojímán jako chyba. ${ }^{32}$ Jedná se ale o druh argumentu, který je uživán zcela běžně. Je adekvátní, aby byl odmítnut? Neschopnost formálního př́istupu vede Toulmina k názoru, že formální validita není vhodným kritériem pro hodnocení argumentů,

31 Toulmin (2003, s. 150, 155, 202).

32 Toulmin (1953a, s. 55, 154), Toulmin (2003, s. 67-69). 
naopak považuje ji za absurdní až nebezpečnou.33 Argumenty např. o počasí, kde je východiskem tvrzení o faktech v přítomnosti, případně v minulosti, a závěrem tvrzení o faktech v budoucnosti, by totiž nebylo možné hodnotit jako platné a meteorologie by skončila jako iracionální podnik, za který by se měl udělovat nejvyšší trest.

Pokud je ale platnost závislá na kontextu, či lépe doméně (field), ve které je argument předkládán, pak vyvstává otázka, co tvoří samotný argument argumentem. Existují nějaká univerzální pravidla, univerzální prvky argumentu, nebo může být za argument považováno cokoli podle dané oblasti?34 To je otázka, kterou Toulmin řeší s ohledem k rozlišení prvkůn, které jsou doménově-závislé (field-dependent) a naopak doménově-nezávislé (field-invariant). ${ }^{35}$ Toulmin za doménově-závislé považuje standardy pro hodnocení správnosti (soundness), platnosti (validity), přesvědčivosti (cogency) a síly (strength) argumentu. ${ }^{36}$ Prvky doménově-nezávislé tvoří forma argumentu, daná jeho procesním charakterem, a síla (force) modálních operátorů. ${ }^{37}$

\section{Model argumentu}

Předkládání jednotlivých prvků argumentu je proces, který je možné popsat jako předkládání odpovědí na otázky. Představení argumentu začíná předložením stanoviska (C, claim), pokračuje přes data (D, datum),${ }^{38}$ následně princip (W, warrant), poté kvalifikátor ( $\mathrm{Q}$, qualifier) a výjimku ( $\mathrm{R}$, rebuttal) až k podpoře (B, backing). Těchto šest prvků vytváří model (viz Schéma 3), který znázorňuje vztah mezi stanoviskem a přijatými daty pomocí principu, který je omezen kvalifikátorem a výjimkami a ukotven v určité doméně podporou. Každý z těchto prvků má určitá specifika, kterým bude věnována následující část.

33 Toulmin (2003, s. 148, 161).

34 Tato problematika je rozsáhlejší, než je zde možno uvést. Tomuto problému se podrobně věnoval Goodnight (1993), který navrhl vlastní řešení pomocí rozšiřrení Toulminova modelu o legitimizační inferenci.

35 Toulmin (2003, s. 15).

36 Tamtéž, s. 137.

37 Tamtéž, s. 35 .

38 Také označována jako základ (grounds), viz Toulmin, Rieke \& Janik (1984). 
Stanovisko je základním prvkem argumentu. Je to to, co je tvrzeno se záměrem, aby si jej druhý všiml a přijal jej. ${ }^{39}$ Je vlastně odpovědí na otázku „Co chceš říci?“" nebo „Jaký názor zastáváš?“.40 Každé stanovisko je tvrzením. Nicméně ne každé tvrzení je stanoviskem. Každé stanovisko je dáno v tvrzení, které je někým vysloveno. Mưže být nicméně obsaženo v tomto tvrzení implicitně. $\mathrm{V}$ takovém případě je možné jej explikovat pomocí parafrázování. U každého stanoviska může být mluvčí v případě potřeby vyzván k jeho obhajobě. ${ }^{41}$

Pokud je mluvčí vyzván k obhajobě stanoviska např. otázkou „Co k tomu máš?“",42 pak prvním krokem v Toulminově modelu je předložení dat (data). Data jsou fakta, informace nebo obecně tvrzení, na kterých je naše stanovisko založeno. Jsou základní bází, která musí být ustavena, aby bylo možné předložit daný argument. Nicméně ustavení této báze může samo vyžadovat předběžný argument, který umožní přijatelnost předložených dat. ${ }^{43}$

Struktura stanovisko-data může být sama chápána jako nejjednodušší struktura argumentu. Nicméně projejí úplnost je třeba doložit vztah mezi daty a stanoviskem, tedy zodpovědět otázku „Jak to spolu souvisí?“.44 Odpověd' pak poskytuje princip. Princip je základ pro spojení dat astanoviska.Můžemítcharakterpokud-pak:Pokudplatídata,pakjeplatné stanovisko. ${ }^{45}$ Není ale vhodné plést si princip s pouhým podmínkovým tvrzením, které by mohlo připomínat implikaci. Princip může mít podobu „Data D umožňují utvořit stanovisko C.“ nebo „S ohledem k datům

39 Toulmin (2003, s. 11).

40 Toulmin uvádí následující otázky ke stanovisku, viz Toulmin, Rieke \& Janik (1984, S. 25): „What exactly are we discussing? Where precisely are we to stand on this issue? And what position must we consider agreeing to as the outcome of the argument?"

41 Toulmin (2003, s. 12).

42 V originále Toulmin (2003, s. 13, 90, 91, 130): „What have you got to go on?“ Později doplňuje následující otázky, viz Toulmin, Rieke \& Janik (1984, s. 26): „What information are you going on? What grounds is your claim based on? Where must we ourselves begin if we are to see whether we can take the step you propose and so end by agreeing to your claim?"

43 Toulmin (2003, s. 90).

44 Srovnej Toulmin (2003, s. 91): „How do you get there?“ S tímto mohou souviset i následující otázky, viz Toulmin, Rieke \& Janik (1984, s. 26): „Given that starting point, how do you justify the move from these grounds to that claim? What road do you take to get from this starting point to that destination?"

45 Srovnej Toulmin (2003, s. 92). 
D lze říci, že C.“. ${ }^{46}$ Toulmin označuje princip jako přemostujúcí turzení (bridgelike statement), které má hypotetickou povahu. ${ }^{47}$

Princip je zároveň něčím, co je v běžném životě často předkládáno implicitně. Pro jeho mnohdy triviální povahu jej zpravidla není třeba, na rozdíl od dat, explikovat. ${ }^{48}$ Principy jsou obecné, určující platnost všech argumentů určitého logického typu. ${ }^{49}$ Toulmin je v př́padě práva přirovnává $\mathrm{k}$ otázkám o zákonech, zatímco data určuje jako otázky o faktech..$^{\circ}$

Stanovisko, data a jejich spojení pomocí principu vytváří základní jednoduchý model argumentu (viz Schéma 3.). Tento model takévystihuje definici argumentu jako souboru alespoň dvou tvrzení (stanoviska a dat) v takovém vztahu, kde každé z tvrzení podporuje jiné tvrzení nebo je jiným tvrzením podporováno (princip).

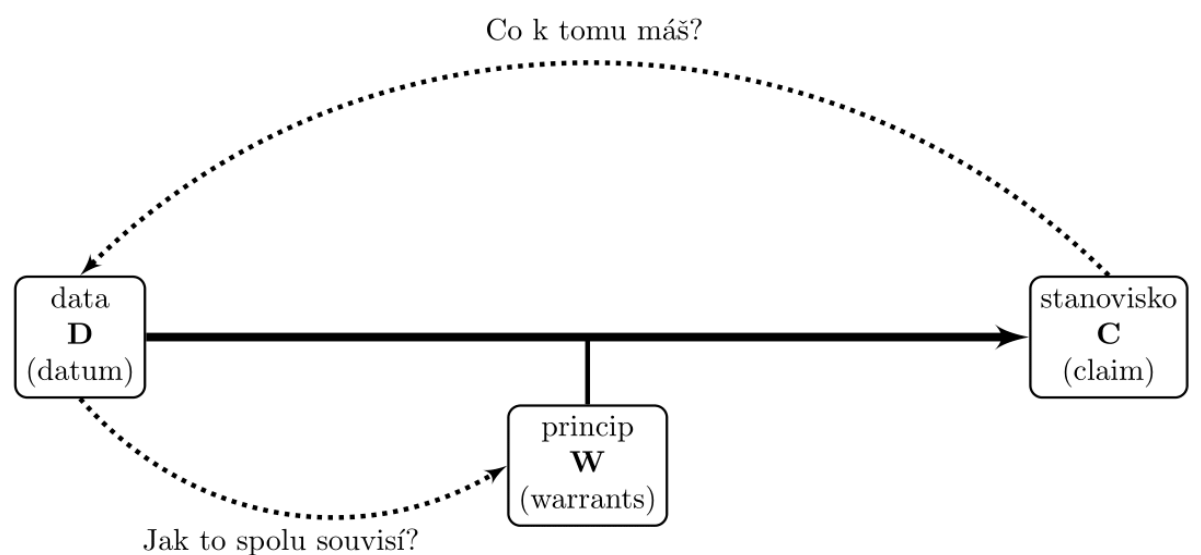

Schéma 3: Základní model argumentu

Princip sám určuje také sílu platnosti toho, co je možné z dat vyvodit. Zatímco v některých př́padech mohou data podporovat stanovisko jako

46 Tamtéž, s. 91.

47 Viz tamtéž, s. 98.

48 Srovnej tamtéž, s. 91: „data are appealed to explicitly, warrants implicitly“.

49 Freeman (2005) se pokusil předložit základní typologii principů, kdy rozlišil apriorní, empirický, institucionální a hodnotící.

50 Toulmin (2003, s. 92). 
nutně platné, ve většině př́ípadů budou spíše podporovat určitou míru jeho platnosti. Většinou tedy data povedou ke stanovisku, které bude s velkou mírou jistoty, spíše, nebo pravděpodobně platné. ${ }^{1}$ Otázka na sílu platnosti může znít: „Je tomu tak nutně?“52

Tato otázka může být zodpovězena specifikováním míry platnosti závěru pomocí kvalifikátoru. KvalifikátoryToulmin pojímá jako modální kvalifikátory, tedy určení možnosti nastání, nikoli pravděpodobnosti, byt i to by bylo možné pod kvalifikátory řadit, s ohledem k myslitelnému možnému souboru tvrzení, která jsou pravdivá. Mezi slova označující kvalifikátor řadí Toulmin např.: nutně; jistě; předpokládatelně; s největší pravděpodobností; jak jen data nasvědčují; s ohledem k tomu, co lze říci; zdá se; velmi možně; možná; evidentně; je to věrohodné; vypadá to tak. ${ }^{53}$

Princip může mít omezení nejenom v síle, která se vztahuje ke stanovisku, ale také $\mathrm{v}$ konkrétních případech. V tomto ohledu se tedy lze ptát, zda platí princip v každém případě. Případy, ve kterých princip neplatí, jsou poté dány jako výjimky. Jedná se o takové situace, kdy i přes platnost dat nelze tato data aplikovat na podporu závěru. ${ }^{54}$ Výjimka je specifickým prvkem v Toulminově přístupu a odlišuje jej od mnoha dalších (ve Waltonově přístupu ani v pragma-dialektice se s výjimkou jako zvláštní součástí struktury argumentu nepracuje, ale je možné ji analyzovat nap̌r. v rámci kritických otázek). Výjimky jsou neobyčejnými situacemi, něčím zvláštním, co běžně nenastává, a není tak zpravidla uvažováno. Obecně jsou dány jako odpověd’ na otázku: „Kdy obecné pravidlo neplatí?" 55 Výjimky jsou velmi specifickým příspěvkem Toulmina k analýze argumentů, nebot’ začleňují do samotné analýzy argumentu konkrétní možnosti jeho neplatnosti. Zároveň také ukazují možnosti argumentačního principu v daném argumentu. ${ }^{56}$

\section{Tamtéž, s. 93 .}

52 Srovnej van Eemeren et al. (2014, s. 218). Toulmin ukazuje např. následující otázky, viz Toulmin, Rieke \& Janik (1984, s. 86): „I mean — are you making this claim unconditionally and without qualification? Are you saying that it's certainly and necessarily so, or only that it's probably, very likely, or quite possibly the case?"“

53 Toulmin (2003, s. 86).

54 Tamtéž, s. 94.

55 V originále van Eemeren et al. (2014, s. 218): „When does the general rule not apply?“

56 Srovnej Freeman (1992). 
Poslední složkou argumentu je pak podpora. Podpora je tím, co dává platnost principu. Je také tím, co určuje náležení argumentu do určité domény. Pokud hovoříme $\mathrm{v}$ právním kontextu, pak podpora zakládá odkaz na platnost zákonů. ${ }^{57}$ Pokud hovoříme $\mathrm{v}$ morálním kontextu, pak podpora odkazuje $\mathrm{k}$ danému morálnímu systému. $\mathrm{V}$ př́ípadě vědy může odkazovat na specifickou metodologii apod. ${ }^{8}$ Podpora je tím, co zakládá možnost hodnocení argumentu stran jeho užití (kritéria pro užití) a ustavuje doménovou závislost pro hodnocení platnosti argumentu. Protože doménové určení je v praxi v mnoha případech evidentní, není zvláštní, že se podpora nevyjadřuje explicitně. Pokud bychom ji chtěli zjistit, je možné se na ni ptát otázkou: „Co ti umožňuje usuzovat z dat na stanovisko?“59

I když jednotlivé složky argumentu nemusí být vždy explicitně vyjádřeny, mělo by být možné je vždy analyzovat, rekonstruovat. Díky tomu lze předložit idealizovanou podobu diskuze, která by měla následující průběh:

\section{Q1: Co tvrdíš?}

A1: C.

Q2: Co máš k C?

A2: D.

Q3: Jak spolu souvisí C a D?

A3: W.

Q4: Je díky W a D nutně C?

A4: Q.

Q5: Bude W platit ve všech př́padech?

A5: R

Q6: Co umožňuje usuzování z D na C?

A6: B

57 Toulmin u právního kontextu uvádí následující otázku vztahující se k podpoře, viz Toulmin, Rieke \& Janik (1984, s. 67): „Can we find proper support for this warrant in the common law, statutes, administrative regulations, codes and so on currently accepted as valid, binding, and authoritative ("in force") within the relevant jurisdiction?"

58 U vědeckého kontextu Toulmin uvádí otázku, viz Toulmin, Rieke \& Janik (1984, s. 68): „Can we find support for this way of arguing in currently accepted theories that rest on adequate experimental evidence or other observations and are in proper accord with our long-established ideas about the general workings of nature?"

59 Srovnej van Eemeren et al. (2014, s. 218). Toulmin ukazuje specifické otázky u různých kontextů, viz např. Toulmin, Rieke \& Janik (1984, s. 67-69). 
Celý model argumentu má pak podobu vyjádřenou ve Schématu 4.

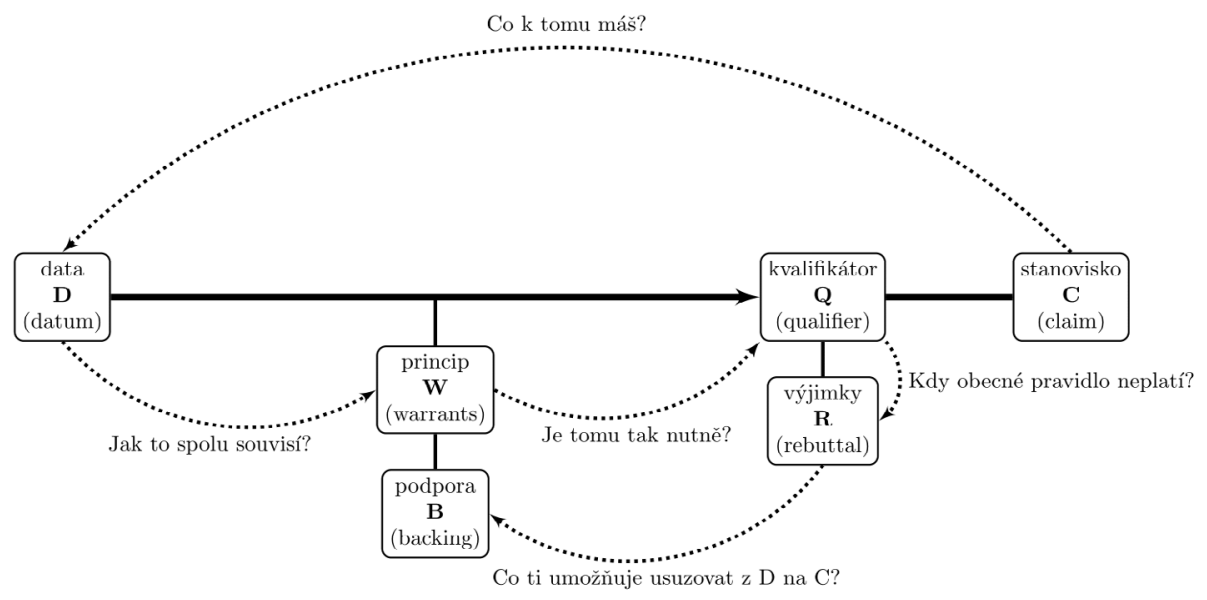

Schéma 4: Toulminův model argumentu

Tento model argumentu je pravděpodobně Toulminovým nejznámějším příspěvkem v teorii argumentace. Je využíván v rámci široké plejády oborů, které se věnují komunikaci. Jeho užívání není nicméně bez obtíží. Při využití tohoto modelu je třeba mít na paměti, že Toulmin jej zamýšlel jako nástroj pro pomoc v praxi. Praxe je zároveň dost komplikovaná a ne vždy je jasné, jak by měl být nějaký materiál pojímán. $\mathrm{V}$ tomto ohledu se pak vyskytují potiže, když je upřednostněn model na úkor daného př́kladu. ${ }^{60}$

Je třeba také mít na paměti, že i samotný Toulmin zmiňuje určité variace svého modelu, jako je doplnění o předběžný argument na podporu dat. ${ }^{61}$ Existují i další variace Toulminova modelu, kdy některé jsou odlišné pouze rozložením prvků, jiné vidí odlišné vztahy mezi prvky, či doplňují další prvky a vlastní vztahy. ${ }^{62}$ Při každém modelu nebo variaci je ale třeba mít na paměti, že jsou zde omezení daná teoretickými

6o Některé z problémů užívání Toulminova modelu zmiňují a na praktických příkladech ilustrují Gasper \& George (1998). Za hlavní potíž považují př́lišnou snahu vše začleňovat do modelu a vložit pod dané prvky. To totiž ve výsledku vede ke karikovaní toho, co se skutečně v praxi odehrává.

61 Toulmin (2003, s. 90).

62 Srovnej Freeman (1985). 
východisky. Teprve pokud jsou tato omezení a východiska respektována, pak je možné modely považovat za užitečný nástroj pro analýzu. ${ }^{63}$

\section{Typy argumentů}

Toulmin odlišuje dva základní typy argumentů: analytické (analytic) a substanční (substantial). Analytické argumenty jsou v principu takové argumenty, ve kterých je $\mathrm{v}$ rámci podpory pro princip obsažen také závěr, tedy stanovisko. ${ }^{64}$ Pokud závěr není obsažen v podpoře, pak se jedná o argument substanční. Analytické argumenty jsou tak, na rozdíl od substančních argumentů, z principu tautologické. Jsou také snadno zachytitelné pomocí klasické logiky, nebot nutnost platnosti jejich závěru je dána platností premis. To také umožňuje určení formální kvazigeometrické validity těchto argumentů. ${ }^{65}$ Pro rozpoznání analytických argumentů navrhuje Toulmin tři testy: tautologický, verifikační a sebeevidenční. ${ }^{66}$

Tautologický test je postaven na tom, co již bylo řečeno, tedy na tom, že analytické argumenty obsahují závěr ve svých východiscích. Tento test je možné provést tím způsobem, že jsou parafrázována východiska tak, aby bylo zřejmé, že obsahují závěr. Pokud jsou všichni lidé smrtelní tvorové a sportovci jsou lidé, jsou, jinými slovy, sportovci smrtelní.

Nicméně tautologický test není dostatečný pro vše, co by si Toulmin přál označit jako analytický argument. ${ }^{67}$ Ukázkou toho je kvazi sylogismus. Lze uvést následující př́íklad (př. 4.):

P1: Petersen je Švéd.

P2: Ǩímskokatolická církev má ve Švédsku 1\% stoupenců.

Z: Petersen není stoupencem Římskokatolické církve.

63 Srovnej Burleson (1979).

64 Viz Toulmin (2003, s. 116): „An argument from D to C will be called analytic if and only if the backing for the warrant authorising it includes, explicitly or implicitly, the information conveyed in the conclusion itself."

65 Toulmin (2003, s. 114) nebo viz 1.2 výše.

66 Toulmin (2003, s. 121).

67 Tamtéž, s. 101-103. 
Tento argument není tautologií, a není tak možné parafrázovat východiska, aby se ukázal $\mathrm{v}$ nich obsažený závěr. Alternativním způsobem, jak zjistit, zda je argument analytický, je položit si otázku, zda po ověření pravdivosti premis je třeba ověřovat platnost závěru, zda proces ověřování platnosti premis zároveň ověřuje platnost závěru. Pokud tvrdíme, že všichni lidé jsou smrtelní, a chceme toto tvrzení ověřit, pak musíme zkontrolovat každého člověka, tedy i všechny sportovce. Při ověřování premis tak ověřujeme nutněi závěr. To přitom bude platnéi pro kvazi-sylogismy. Pokud budeme ověřovat, zda platí, že Římskokatolická církev má ve Švédsku 1 \% stoupenců, pak je třeba dotázat se všech Švédů, a tím také Petersena. I když se může stát, že Petersen bude stoupencem Řimskokatolické církve, samotné ověření premis stačí k tomu, abychom to zjistili.

Posledním zpo̊sobem testu analytičnosti argumentu je sebe-evidence jeho platnosti. Je třeba, abychom prokazovali platnost argumentu? Nebo se jeho platnost jeví jako sebe-evidentní? V případě tradičních sylogismů se zdá, že není třeba dále prokazovat jejich platnost a obdobně je tomu i v př́ipadě kvazi-sylogismů.

Substanční argumenty jsou podle Toulmina mnohdy tvořeny tvrzeními o rozdílných logických typech. ${ }^{68}$ Tyto argumenty tedy nejsou formálně validní, nicméně jsou $\mathrm{v}$ praxi běžně přítomné. Validita u substančních argumentů je dána adekvátní procedurou jejich užití s ohledem k doméně, ve které se vyskytují. Argumenty o budoucnosti, např. o počasí, by tak měly být hodnoceny s ohledem $\mathrm{k}$ tomu, zda odpovídají dané doméně, kterou může být meteorologie, spíše než aby byly zavrženy a jejich předkladatelé hrdelně trestáni.

Toulmin také rozlišuje argumenty na základě toho, zda užívají princip (warrant-using) nebo ustavuǰ princip (warrantestablishing). ${ }^{69}$ Zatímco první druh argumentů se odvolává na princip, který je obecně přijímaný, druhý typ musí předložit podporu pro princip důkazem, že data mají vztah podpory ke stanovisku. Argumenty ustavující princip jsou takové, kde právě princip je nový, a je tedy tím, co je třeba prokázat. ${ }^{0}$ Tyto argumenty je možné si

68 Viz 1.3 výše.

69 Toulmin (2003, s. 111-112).

70 Tamtéž, s. 112. 
představit jako důkazy o korelaci mezi jevy, která je nově objevena. Je třeba samostatně prokázat, že jak data, tak stanovisko jsou platné, a tím prokázat princip jejich spojení.

Další rozlišení argumentů je postavené na tom, zda je stanovisko provizorni (tentative) nebo nezvratné (conclusive). ${ }^{71}$ Tedy zda je stanovisko podpořeno pouze $\mathrm{s}$ omezenou mírou pravdivosti, nebo je naopak nutně pravdivé. Nakonec všechna dělení argumentů jsou běžně chápána jako spadající pod rozlišení deduktivních (deductive) a induktivnich (inductive) argumenti̊. Nicméně podle Toulmina jsou deduktivní argumenty v závěru odlišné pouze tím, že užívají princip, který je obecně přijímaný. ${ }^{72,73}$

\section{Analýza}

Toulminůvmodelumožňujezákladníanalýzuargumentu. Díky procesnímu pojetípřitomdáváivýchozíotázkyprourčeníjednotlivýchprvků.Užsamotné určení těchto prvků nám mủžeo daném argumentu říci mnohem více. Může ukázat, jaké logické typy jsou v daných prvcích užity, a tím také ríci, zda a př́ípadně jaký je zde typový skok. Typový skok je umožněn doménou, do které argument spadá, tedy podporou, která je zvolena pro užitý princip. To nám následně může dát vodítko pro hodnocení argumentu. V př́ípadě Přemluv bábu ${ }^{74}$ je tak možné položit si výzkumnou otázku (V1):

\section{O1: Do jaké domény argumenty v Přemluv bábu náleží?}

A následně tuto otázku doplnit (O1.1):

O1.1: Jaká jsou kritéria pro hodnocení argumentů v Přemluv bábu?

71 Tamtéž, s. 130.

72 Tamtéž, s. 134, 138.

73 Kritiku k Toulminově rozlišení argumentů předložil např. Hamby (2012), který se zaměřil především na analytické argumenty.

74 Issová, Mádl \& Zelenka (2010). Z tohoto zdroje čerpají i všechny dále uvedené ukázky. Odkaz na video a přepis celého textu je k dispozici v editorialu tohoto čísla časopisu na s. 7-9. 
K zodpovězení této otázky je třeba předložit model argumentu a hledat, jaké podpory jsou využity pro principy v daných spojeních. Aby to ale bylo možné, je třeba nejprve určit další prvky jednotlivých argumentů. Postup analýzy odpovídá procesnímu př́stupu k argumentu, a zakládá se tedy na postupném kladení otázek a odpovědí na ně. S ohledem k využití Toulminova př́stupu není při této analýze potřebné rozlišovat mezi jednotlivými mluvčími (Marthou Issovou a Jiřím Mádlem). Oba mluvčí jsou pojímáni jako zastánci jedné strany v diskuzi.

\subsection{Základní prvky}

Prvním krokem $\mathrm{v}$ analýze je určení toho, co je samotným předmětem daného videa, co je stanoviskem, o jehož přijetí má být př́ijemce přesvědčen. Co tedy chtějí autoři videa říci? $\mathrm{V}$ dané ukázce je proklamované stanovisko $(\mathrm{C})$ :

„My natáčíme tohleto video, abysme vás přesvědčili, že se prostě máte sebrat, koupit si lístek na autobus nebo na vlak nebo nasednout do auta a rozjet se za svejma prarodičema nebo rodičema na venkov a přesvědčit je, že mají volit pravici.“

To lze parafrázovat následujícím způsobem:

C: Př́ijemce sdělení by měl přesvědčit své rodiče/prarodiče $\mathrm{k}$ volbě pravicové strany.

Stanovisku (C) odpovídá i pojmenování videa (Přemluv bábu). Na jakém základě je pak toto stanovisko postavené? Byt’ se jedná o krátkou ukázku, lze zde nalézt celou řadu informací, nicméně ne všechny se vztahují přímo ke stanovisku. Kde je tedy to, co je třeba pro přijetí stanoviska? $\mathrm{S}$ ohledem $\mathrm{k}$ tomu, že stanovisko př́jemce vyzývá $\mathrm{k}$ určité akci, lze se ptát: Proč bychom tuto akci měli podniknout? Co je tvrzeno ve vztahu $\mathrm{k}$ tomu, že by př́jemce měl přesvědčit své příbuzné $\mathrm{k}$ volbě pravicové strany? V první řadě jsou zde data, která určují spojení starých lidí s možným vítězstvím levicových stran: 
„Jestli v týhle zemi zvítězí u příštích voleb levice, tak za to budou moct starý lidi, protože to jsou ty, který levici volej.“

Tedy:

D1: Staří lidé budou volit levici.

Toto tvrzení je ale problematizováno, tedy jsou zde předjímány možné potíže s prijijetím D1:

„Ne, jak je možný, že tu levici volej? Copak voni zapomněli, jak to tady těch čtyřicet let, co byli komunisti u moci, vypadalo?"

Tvrzení D1 je tak dále podpořeno odkazem na mentální charakteristiku starých lidí:

„Starý lidi mají totiž tzv. selektivní pamět. To znamená, že si pamatujou jenom ty hezký věci. Jak si dali poprvé pusu na taneční zábavě, ale už třeba úplně zapomněli na proces s Miladou Horákovou... (...)

Komunisti přinutili nejlepší lidi týhletý země k emigraci Miloše Formana ... Miloše Formana, Navrátilovou, Kunderu... Milana Kunderu.“

Tedy:

D1.1: Staří lidé nejsou schopni zhodnotit minulou zkušenost s levicovou vládou.

Je zde něco dalšího mimo D1, co má přímý vztah k závěru C? Pokud v D1 byli určeni staří lidé jako možní voliči levice, je nyní třeba dát je do vztahu k př́ijemci. V ukázce je tak následně ustanoveno, že tito lidé mohou být součástí rodiny př́ijemce: 
„To můžou bejt lidi z vaší rodiny. To může bejt vaše teta, váš strejda, vaše babička... ... váš děda.“

Tedy:

D2: Staří lidé mohou být součástí rodiny př́ijemce.

V D1 a D2 je určena odpovědnost skupiny osob (staří lidé) za nějakou možnou situaci nebo akci (volba levice) a jejich vztah $\mathrm{k}$ př́jjemci (př́buznost). Nicméně to samo nezavdává důvod se proti takovéto akci vymezit. Je tedy třeba určit, proč by mělo být takovémuto počínání zamezeno. Dalš́ část dat se proto vztahuje k tvrzení toho, že vítězství levice by bylo pro příjemce nepříznivé:

„No, hlavně když budete volit levici, tak si pak levice vytře zadek s váma.“

A později také:

„Volit levici je v přímým rozporu se zájmy jejich potomků.“

Tedy:

D3: Vítězství levice by bylo pro př́ijemce nepř́íznivé.

Pouhé konstatování, jakkoli expresivní, toho, že je něco nežádoucí, není zpravidla dostatečné pro přesvědčení nějaké osoby k tomu, aby se k dané akci nějak vymezila nebo něco učinila. Proto je i $\mathrm{D} 3$ dále podpořeno odkazem na konkrétní negativní důsledky, které by to pro př́ijemce mělo:

„Protože levice nadělá dluhy, a zatímco voni si v klidu umřou, tak my je pak budeme do konce života splácet.“

$[\ldots]$ 
„Navíc levice nechce řešit problémy $\mathrm{s}$ důchody, a pokud nedojde $\mathrm{k}$ reformě, tak ve státní kase nebudou na důchody peníze. A kdo nebude mít našetřeno, tak na tom bude hodně špatně. Ale to levici nezajímá, protože její voliči jsou starý dneska a ne za čtyřicet let.

Levice nepřipustí školný, oni totiž rádi hlásaj, že to jakože znepřístupní vzdělání chudším. Jenže to je úplná blbost. Naopak. Vzdělávání u nás v Čechách není moc dobrý, a pokud nedokážeme motivovat školy, aby s tím něco dělaly, tak nám ty nejlepší studenti odejdou do zahraničí. Když nezafunguje zdravej rozum, použijte nátlak. Pro prarodiče jsou jejich vnoučata to nejdůležitější na světě, takže když budou volit pravici, dostanou od vás jednu návštěvu letos zdarma.“

Tedy:

D3.1: Levice nadělá dluhy, nebude řešit problém s důchody a neprripustí školné.

Poslední součástí dat, které je možné najít při argumentech pro nějakou akci, by pak mělo být podpoření úspěšnosti nebo možnosti akce, kterou má př́ijemce vykonat a která může negativním důsledkům zamezit. Poslední část dat tak podporuje to, že je zde možnost přemluvit staré lidi:

„Když nezafunguje zdravej rozum, použijte nátlak. Pro prarodiče jsou jejich vnoučata to nejdůležitější na světě, takže když budou volit pravici, dostanou od vás jednu návštěvu letos zdarma."

Tedy:

D4: Př́ijemce má vliv na volbu svých prarodičů/rodičů. 
V daném materiálu je ještě doplňková část, totiž odměna nebo bonus za vykonání akce dané ve stanovisku. Je zde dán slib, který by bylo také možno analyzovat jako součást argumentu:

„A odměna pro vás, když přemluvíte svoji babičku a svýho dědu?

Poradíme vám, kde na netu najít úplně zadarmo to nejlepší animální anální porno se členkou italský parlamentní strany, Rocco Siffredim a úhořem.“

Tedy:

D5: Př́ijemci je slíbeno získání odměny za přemluvení svých rodičů/prarodičů.

Určení dat a stanoviska nám nyní umožňuje klást otázku, jaký princip je spojuje. $V$ tomto materiálu je přitom princip dán explicitně hned v úvodu:

„Kdybyste věděli, že můžete změnit osud týhle země tím, že navštívíte svoje prarodiče.“

Tedy:

W: Pokud mohu změnit osud této země, měl bych to udělat.

Jedná se vlastně o primitivní princip typu pokud-pak. Nicméně tento princip je s ohledem $\mathrm{k}$ datům a závěru vhodné doplnit o určení charakteru změny, toho, že změna je dobrá:

W': Pokud př́ijemce může změnit osud této země $\mathrm{k}$ lepšímu, měl by to udělat.

Tento princip se pak vztahuje ke všem datům na první úrovni (D1, D2, D3, D4) mimo D5. Platí tento princip vždy? Tato otázka se ptá na 
kvalifikaci závěru. $V$ daném materiálu se nezdá, že by byl závěr omezen, tedy platí nutně. Nicméně je zde explicitně uvedena výjimka z principu:

„Teda pokud nejste úplně...“

Tedy:

R: Př́ijemce má charakter, který způsobuje, že nebude měnit osud země k lepšímu.

Nyní je možné představit základní model argumentu, ve kterém budou zatím zachycena pouze data na první úrovni (D: D1, D2, D3, D4), která se pomocí principu (W') omezeného výjimkou (R) vztahují ke stanovisku (C). Kvalifikátor (Q) a podpora (B) budou zatím ponechány nedoplněné. Viz Schéma 5.

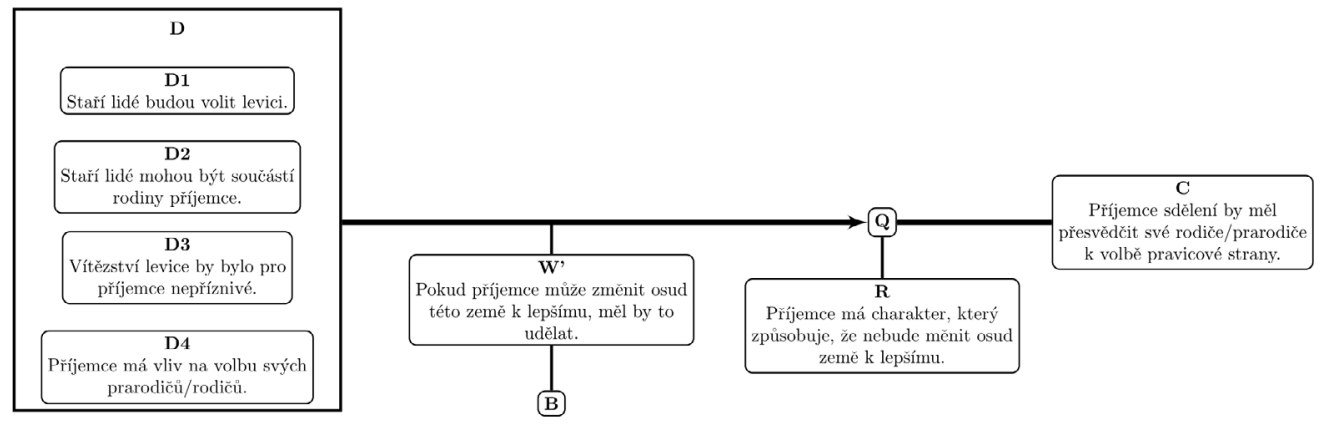

Schéma 5: Model Přemluv bábu v. 1

Pomocí principu a výjimky je možné určit podporu. V Přemluv bábu se jedná o tzv. motivační argument, nebot' má přimět př́ijemce k určité akci. ${ }^{75}$ $\mathrm{V}$ př́ípadě těchto argumentů je třeba hledat podporu v rámci hodnot, tužeb nebo jiných motivů, které mohou dát příčinu k nějakému jednání. Otázka, která zde tedy leží, je ta, zda je princip podpořen odkazem na rozumnost chování ve stanovisku nebo spíše na sobeckost spjatou s osobními výhodami pro jednajícího. Čím je dán onen „lepši“ stav, na který se mluvčí odkazují?

75 Brockriede \& Ehninger (1960, s. 51). 
$\mathrm{Z}$ předložených dat nás $\mathrm{v}$ tomto ohledu zajímá pouze $\mathrm{D}$ 3, nebot’ to jediné je logického typu hodnotového usuzování. Ostatní data (D1, D2, D4) jsou různými variantami tvrzení o faktech. D3 tedy ustavuje hodnotu, a to negativní hodnotu, takovou, které se př́ijemce chcevyhnout, která byla parafrázována jako nepř́znivost. Pokud se podíváme na podporu této hodnoty, lze ukázat, že je dána spíše tvrzeními o výhodách pro jednotlivce nebo skupinu, nikoli pro celek, a v opozici k jiné skupině. Např.:
„my je pak budeme do konce života splácet“
$[\ldots]$
„její voliči jsou starý dneska“

Interpretaci hodnoty $\mathrm{v}$ podpoře jako sobectví také nahrává paradoxně tvrzení, které zatím nebylo analyzováno, totiž:

„Jo, a jestli někdo volí levici kvůli 30 Kč poplatku, dobře, ale je to teda dost sobecký rozhodnutí, který třeba mě poškodí.“

Paradoxní je na něm to, že i když se snaží doložit sobectví druhé osoby, dělá to odkazem na nevýhody, které plynou přímo pro mluvčího jako jednotlivce, tedy odkazem na vlastní, sobecký, zájem. Toto tvrzení je zároveň výjimkou pro podporu (z dat D3.1) poškozující situace (D3):

R3: Změny zamýšlené levicí hodnotí př́ijemce jako pro něj výhodnější a nebere ohled na dopad těchto změn na jiné osoby.

Proti interpretaci hodnoty v podpoře jako sobectví, ale spíše obecněji jako rozumnosti, pak hovoří odkaz na zdravý rozum:

„Když nezafunguje zdravej rozum, použijte nátlak.“ 
Zde je ale třeba vzít do úvahy celé tvrzení. Rozumnost je totiž diskvalifikována, pokud osoba není ochotná naslouchat a př́ípadně změnit svůj postoj. To zde lze dokladovat tím, že jako legitimní prostředek je připuštěn i nátlak.

Pro tyto důvody se zdá adekvátní interpretovat jako hodnotu v podpoře argumentu sobeckost, respektive vlastní zájem, nikoli rozumnost ve smyslu domluvy s dalšími zainteresovanými osobami. Pro účely tohoto článku ale zůstane podpora v modelu jen vyznačenou bez jasného určení. Celý hlavní argument i s podporami pro data je možné zanést do následujícího schématu, viz Schéma 6.

Zcela samostatně stojí data D5. Zde vystupuje jako logický typ slib. V tomto ohledu by rekonstrukce implicitního principu tohoto doplňkového argumentu měla odpovídat tomu, že je žádoucí pro př́jemce, aby získal, co je mu slibováno. Kvalifikátor ani výjimka pro tento argument není určena. Obdobně je tomu s podporou. I tento doplňkový argument je možné zanést do schématu jako samostatnou linii od D5 k C, viz Schéma 7.

\subsection{Hodnocení argumentu}

Určení jednotlivých prvků argumentu a modelu argumentu umožňuje hodnocení argumentu. V první řadě je třeba říci, že se jedná v obou případech, u hlavního i vedlejšího argumentu, o substanční argumenty. Data neobsahují svůj závěr. $V$ př́ípadě hlavního argumentu princip navíc vyžaduje podporu.

V tomto ohledu je hlavní argument hodnocen na základě toho, zda jsou data správně užita podle svého logického typu. Zda jsou tvrzení o faktech pravdivá, zda je hodnotový soud adekvátní apod. Následně je v tomto argumentu možné hodnotit to, zda nenastala výjimka. Hlavním prvkem pro hodnocení je ale podpora, tedy to, zda je vlastní zájem př́ijemce dostatečným důvodem $\mathrm{k}$ tomu, aby se rozjel a přemluvil své rodiče. $\mathrm{V}$ závěru přitom půjde o to, zda změny, které jsou levici připisované, jsou př́ijemcem pokládány za žádoucí nebo nežádoucí. To je především patrné s ohledem k R3, jejíž přijetí by znamenalo ztrátu podpory pro D3, a tím i ztrátu hlavní podpory pro $\mathrm{C}$. 
Tomáš Ondráček
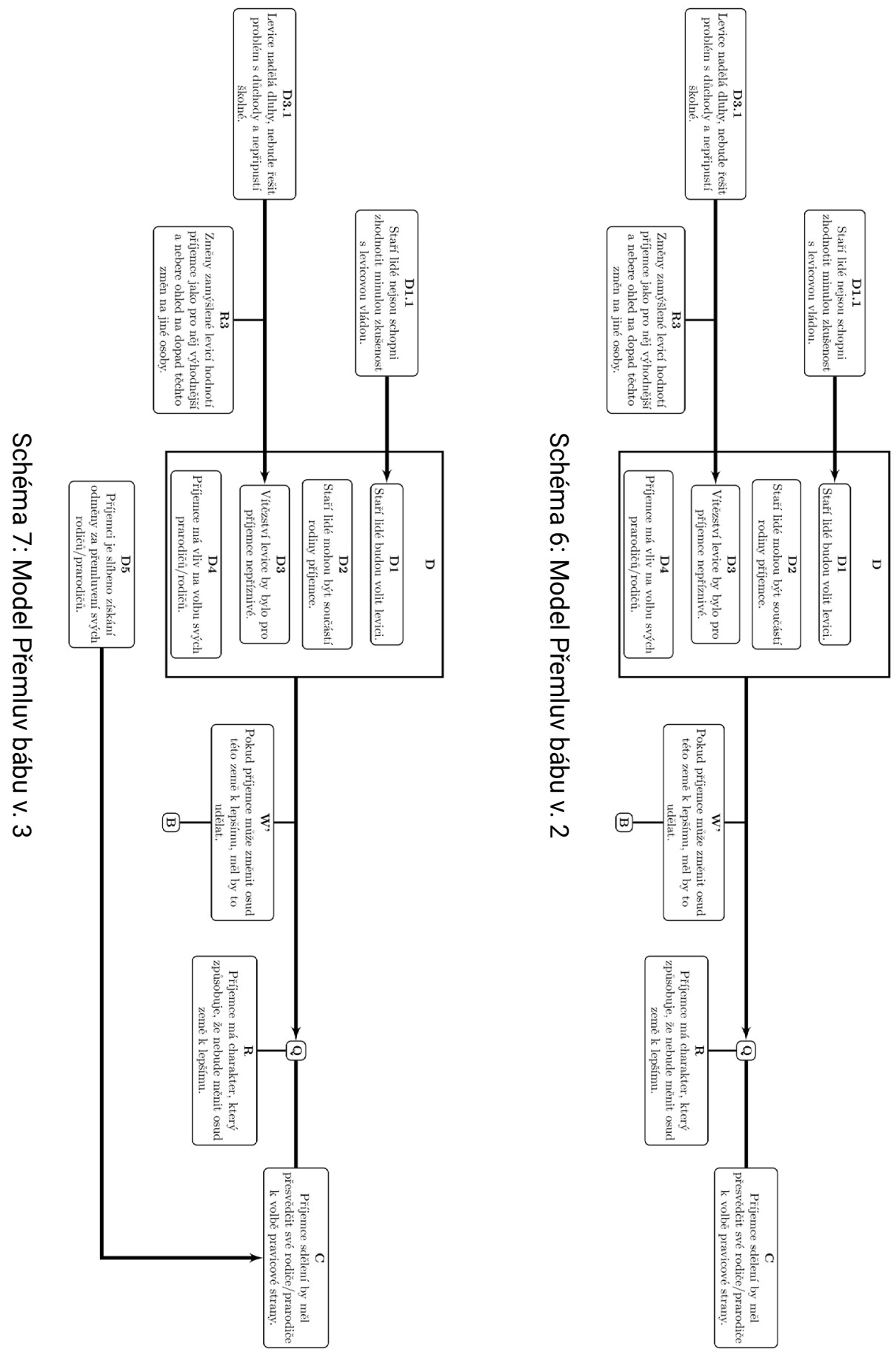
To, zda jsou jednotlivé kroky levice přijatelné nebo nepřijatelné, je dáno charakteristikami v D3.1. Přitom o těchto charakteristikách se předpokládá, že ukazují něco nežádoucího pro př́jemce. Jejich podání je ale velmi specifické. Část z nich je předložena jako osobní dopad, ve kterém je př́ijemce zahrnut do skupiny s mluvčím, což odpovídá i R3:

„my je pak budeme do konce života splácet“

V dalším určení akcí z D3.1 jsou pak rozlišeny tři skupiny - trpící, nezasáhnutá a profitující:
„A kdo nebude mít našetřeno, tak na tom bude hodně špat- ně. Ale to levici nezajímá, protože její voliči jsou starý dneska a ne za čtyřicet let.“

Poslední charakteristika je pak dána prostým popřením důvodu pro původní akci, respektive zdržení se akce, a uvedením situace, u které ale není zřejmé, zda je následkem dané akce, či zdržení se akce:
„... že to jakože znepřístupní vzdělání chudším. Jenže to je úplná blbost. Naopak. Vzdělávání u nás v Čechách není moc dobrý, a pokud nedokážeme motivovat školy, aby s tím něco dělaly, tak nám ty nejlepší studenti odejdou do zahraničí.“

I s ohledem k těmto charakteristikám tak lze říci, že je na př́jemci, zda se ztotožní s tím, že náleží do skupiny mluvčího (bude splácet dluhy), že pojímá své zájmy jako důležitější než zájmy jiné skupiny a není ochoten tomu zabránit (nebude šetřit a zájmy dnešních starých nejsou v tomto ohledu tak významné) a že sleduje stejné cíle, byt není jasně řečeno, jak jich může být dosaženo (dobré vzdělávání).

Hodnocení argumentu se proto ve výsledku bude lišit podle př́ijemce sdělení, podle toho, zda souhlasí s výše uvedenými určeními. To nakonec odpovídá Toulminově pojetí a snaze ukázat, že substanční argumenty mají rozdílná kritéria daná doménou, do které náleží. Pokud se pak jedná o argumenty motivační, které se odvolávají na hodnoty, je možné 
předpokládat, že tyto hodnoty budou rozdílně přijímané u různých př́jemců.

Hodnocení doplňkového argumentu bude $\mathrm{v}$ tomto př́padě závislé na tom, zda je zde uvedený slib použit adekvátně. Pokud bychom hledali kritéria pro použití slibu, je možné je najít $\mathrm{v}$ teorii řečových aktů. ${ }^{76}$ Obecně bychom pak mohli říci, že hlavní podmínkou správného užití slibu, je záměr slibujícího slib naplnit. O tomto záměru lze v doplňkovém argumentu pochybovat hned z několika důvodů. Slíbený objekt se zdá př́liš fantaskní, což zavdává pochyby o jeho existenci a spíše nahrává názoru, že si jej mluvčí vymyslel. To, že se jedná o fantaskní záležitost, také zavdává pochyby o tom, zda je mluvčí přesvědčený, že o to bude příjemce stát. Mluvčí se tak může snažit jako slib předložit něco, co nemá v plánu splnit, nebot’ nepočítá $\mathrm{s}$ tím, že by to bylo požadováno. Tomu, že se nejedná o slib, pak nahrává také to, že rada k nalezení daného záznamu nebyla nikdy dána, a to i přes explicitní žádosti.

Pokud je tedy $\mathrm{v}$ doplňkovém argumentu použit slib chybně, pak lze říci, že se nejedná o platný argument $\mathrm{v}$ Toulminově pohledu. Tento slib zde působí jako rétorický prvek, který má spíše upoutat pozornost příjemce, případně mu pomoci identifikovat se s mluvčím, ale nikoli jako součást argumentu. Schéma argumentu by pak bylo možné vyznačit následovně, viz Schéma 8 . Schéma 8: Model Přemluv bábu v. 4

\section{Přehled a závěr}

Mezi teoriemi argumentace má Toulminův přístup nejen historicky nezanedbatelné místo, ale i v dnešní době může sloužit mnoha účelům. Podává dobrý návod na základní analýzu a také způsob, jak této analýze vyučovat. Velkou výhodou je jeho procesní pojetí, kdy je stanoven postup předkládání jednotlivých částí. Tento model je tak vhodným nástrojem pro první seznámení se nejen s argumenty, ale i s argumentací obecně. Postup od toho, co je vlastně hlavním předmětem diskuze, tedy stanoviska, až k určení specifik diskuze, která mohou sloužit pro následovné ověřování platnosti argumentu, se zdá velmi přirozený.

76 Austin (1962), Searle (1969). 


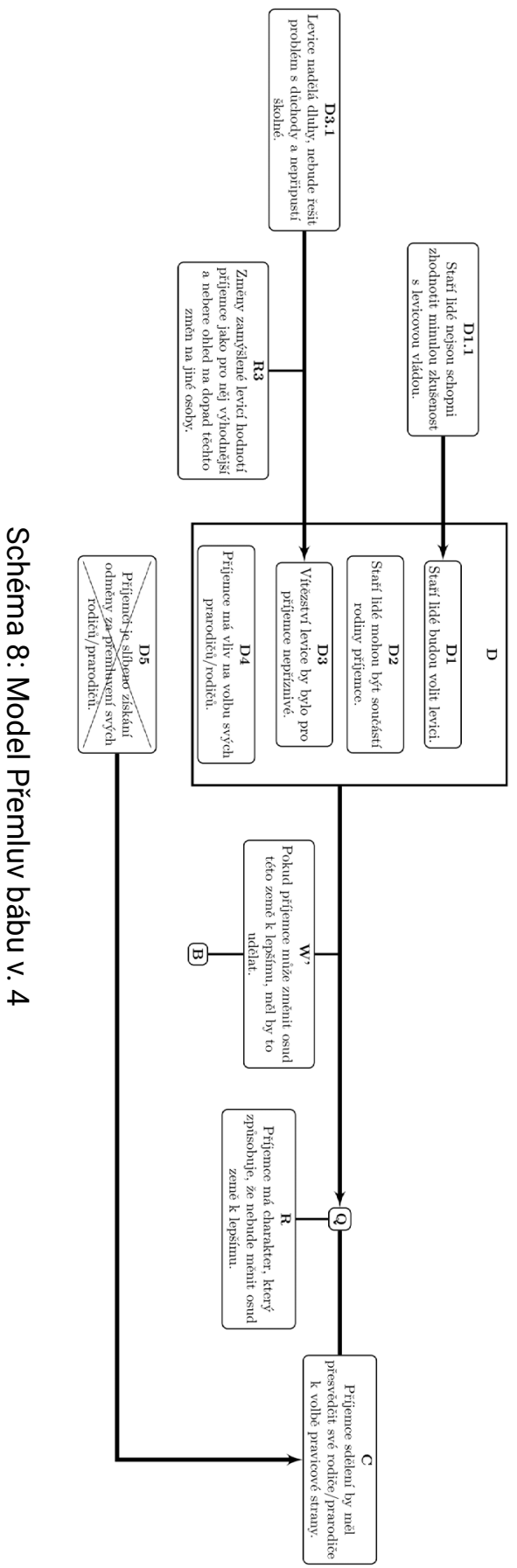


Nicméně Toulmin není pouhým dobrým zjednodušením pro výukové účely. ${ }^{77} \mathrm{I} v \mathrm{v}$ rámci teorie je Toulminův přístup stále zajímavým. Hitchcock a Verheij poukazují na pět prvků, které jsou zajímavé i pro dnešní výzkum $\mathrm{v}$ argumentaci. ${ }^{78} \mathrm{~V}$ první řadě se jedná o zapojení vyvrácení, námitek nebo útoků do vlastního uvažování, jak to dělá Toulmin u výjimek. Druhým zajímavým rysem je kvalifikování stanoviska nebo závěru, tedy omezení platnosti principu. Zatím stále př́tomným rysem mnoha př́stupu je idealizace formální validity a formálních přistupů obecně. Ve třetím bodě je to proto Toulminova obhajoba toho, že jsou zde dobré platné argumenty, které formální kritéria nesplňují. Za čtvrté je tu poté otázka nevyřčených předpokladů, presupozic, které spojují východiska, data a závěry, stanoviska. Tyto předpoklady je podle Toulmina lépe uvažovat jako záruky spojení, principy nebo jejich podporu, spíše než jako implicitní premisy. A na závěr je tu Toulminovo pojetí doménové závislosti pro hodnocení argumentů.

Ohledně posledního bodu je dobré připojit také otázku logických typů. Ta odlišuje platnost pro tvrzení a další jazykové objekty nejen na úrovni domény ale i jejího jazykového charakteru. Logické typy poukazují na to, že kritéria pro přijetí tvrzení se mohou lišit, pokud dané tvrzení pojednává o budoucnosti, minulosti, vyjadřuje estetický soud apod. To lze využít pro zhodnocení podmínek pro přijetí celého argumentu, jak bylo v analýze ukázáno v doplňkovém argumentu.

Pokud se týká samotného materiálu, pak je možné nyní formulovat odpověd' na výzkumnou otázku O1, totiž z jaké domény jsou podpory argumentů $\mathrm{v}$ daném materiálu. $\mathrm{V}$ př́padě hlavního argumentu se jedná o doménu hodnot. To je dáno tím, že se jedná o motivační argument. Nicméně jednoznačné určení konkrétní hodnoty bude závislé na příjemci. Byly identifikovány dvě nejpravděpodobnější hodnoty, rozumnost a sobectví, a i přesto, že se sobectví zdá být pravděpodobnější vzhledem $\mathrm{k}$ prezentovaným tvrzením, rozumnost nelze zcela vyloučit. Určení rozumnosti, jako hlavní hodnoty, by navíc mohlo být ve prospěch mluvčích.

77 Př́ípadně i k analýze učebního procesu, viz Leitão (2001) nebo Smyrnaiou et al. (2018).

78 Hitchcock \& Verheij (2005, s. 255). 
Dále je možné ukázat, že při analýze doplňující otázky O1.1 bylo výhodné analyzovat doplňkový argument (z D5 do C) v materiálu, který byl postaven na slibu (D5). Zatímco logické typy v hlavním argumentu se zdají naplňovat podmínky svého užití, v doplňkovém argumentu jsou silné důvody pro to, myslet si, že slib je zde užit neadekvátně, bez záměru jej slibující stranou naplnit. Doplňkový argument je možné hodnotit jako neplatný, na rozdíl od hlavního argumentu, jehož hodnocení bude dáno př́jemci podle jejich identifikace se $s$ hodnotami v podpoře.

Ačkoli analýza nesrovnávala různé argumenty z odlišných domén, ukázalo se v ní, že i v rámci jedné domény lze hledat rozdílné podpory pro princip. Přitom ne vždy může být rozhodnutelné, o jakou podporu se jedná. I když se zdá, že je lépe pojímat daný materiál jako apel na sobeckost, s ohledem k rozdílným nárokům př́ijemců zůstává nejasné, zda tomu tak je, zda se opravdu jedná o apel na sobeckost nebo o apel na rozumnost. Tato nejasnost nicméně může být výhodou při předkládání daného sdělení, nebot může snadněji zasáhnout širší publikum, a mít tak více vlivu.

\section{Literatura}

Abelson, R. (1961): „In Defense of Formal Logic.“ Philosophy and Phenomenological Research 21 (3): 333-346. DOI: $10.2307 / 2105150$.

Aikin, S. F. (2010): Epistemology and the Regress Problem. Routledge, New York.

Aristotelés (1961): První analytiky. Československá akademie věd, Praha.

Austin, J. L. (1962): How to do things with words: The William James lectures delivered at Harvard University in 1955. The Clarendon Press, Oxford.

Bird, O. (1961): „The Re-discovery of the Topics.“ Mind 70 (280): 534539.

Brockriede, W. \& Ehninger, D. (1960): „Toulmin on argument: An interpretation and application." Quarterly Journal of Speech 46 (1): 44-53. DOI: 10.1080/00335636009382390.

Burleson, B. R. (1979): „On the Analysis and Criticism of Arguments: Some Theoretical and Methodological Considerations." The 
Journal of the American Forensic Association 15 (3): 137-147.

DOI: $10.1080 / 00028533.1979 .11951143$.

Castaneda, H. N. (1960): „On a proposed revolution in

logic.“ Philosophy of Science 27 (3): 279-292. DOI:

$10.1086 / 287747$.

Cooley, J. C. (1959): „On Mr. Toulmin's revolution in logic.“ The Journal of Philosophy 56 (7): 297-319. DOI: 10.2307/2021996.

Coquand, T. (2018): „Type Theory.“ In The Stanford Encyclopedia of Philosophy, eds. E. N. Zalta, (Fall 2018 Edition), Dostupné z: https://plato.stanford.edu/archives/fall2018/entries/typetheory/.

Cowan, J. L. (1964): „The Uses of Argument - An Apology for Logic.“ Mind 73 (289): 27-45.

van Eemeren, F. H., Garssen, B., Krabbe, E. C., Snoeck Henkemans, A. F., Verheij, B. \& Wagemans, J. H. (2014): Handbook of Argumentation Theory. Springer, Dordrecht.

Freeman, J. B. (1985): „Dialectical Situations and Argument Analysis.“ Informal Logic 7 (2-3): 151-162. DOI: 10.22329/il.v7i2.2713.

Freeman, J. B. (1992): „Relevance, Warrants, Backing, Inductive Support.“ Argumentation 6 (2): 219-275. DOI: $10.1007 /$ BFo0154327.

Freeman, J. B. (2005): „Systematizing Toulmin's Warrants: An Epistemic Approach.“ Argumentation 19 (3): 331-346. DOI: 10.1007/s10503-005-4420-0.

Gasper, D. R. \& George, R. V. (1998): „Analyzing Argumentation in Planning and Public Policy: Assessing, Improving, and Transcending the Toulmin Model." Environment and Planning B: Planning and Design 25 (3): 367-390. DOI: 10.1068/ b250367.

Goodnight, G. T. (1993): „Legitimation Inferences: An Additional Component for the Toulmin Model.“ Informal Logic 15 (1): 41-52. DOI: 10.22329/il.v15i1.2468.

Hamby, B. (2012): „Toulmin's „Analytic Arguments“.“ Informal Logic 32 (1): 116-131. DOI: 10.22329/il.v32i1.3099. 
Hitchcock, D. \& Verheij, B. (2005): „The Toulmin Model Today: Introduction to the Special Issue on Contemporary Work using Stephen Edelston Toulmin's Layout of Arguments.“ Argumentation 19 (3): 255-258. DOI: 10.1007/s10503-0054414-y.

Hitchcock, D. \& Verheij, B., eds. (2006): Arguing on the Toulmin model. Springer, Dordrecht.

Issová, M., Mádl, J. \& Zelenka, P. (2010): „Přemluv bábu.“ In Youtube [online]. 22. 4. 2010 [cit. 8. 11. 2018]. Dostupné z: https://www. youtube.com/watch?v=MLfFhdcXJhA.

Karbach, J. (1987): „Using Toulmin's model of argumentation.“ Journal of Teaching Writing 6 (1): 81-92.

Kneupper, C. W. (1978): „Teaching Argument: An Introduction to the Toulmin Model." College Composition and Communication 29 (3): 237-241.

Leitão, S. (2001): „Analyzing Changes in View During Argumentation: A Quest for Method." Forum Qualitative Sozialforschung/ Forum: Qualitative Social Research 2 (3). DOI: 10.17169/fqs2.3.907.

O'Connor, D. J. (1959): „The Uses of Argument.“ Philosophy 34 (130): 244-245. DOI: 10.1017/Soo31819100037220.

O'Hara, R. (2006): Publications of Stephen Toulmin: A Working

Bibliography. Dostupné z: http://dx.doi.org/10.2139/ ssrn.2542900.

Ryle, G. (2009): The Concept of Mind. Routledge, Londýn. Searle, J. R. (1969): Speech Acts: An essay in the philosophy of language. Cambridge University Press, Cambridge.

Smyrnaiou, Z., Petropoulou, E., Georgakopoulou, E. \& Sotiriou, M. (2018): „Tracing Students' Quality of Argumentation in Simulated Parliament Activities." In Electronic Proceedings of the ESERA 2018 Conference. Part 7, Strand 7, Dublin City University, Dublin, 2018, s. 960-971.

Toulmin, S. E. (1953a): An Examination of the Place of Reason in Ethics. Cambridge University Press, Cambridge. 
Toulmin, S. E. (1953b): The Philosophy of Science: An Introduction. Hutchinson, London.

Toulmin, S. E. (1976): Knowing and acting. Macmillan Publishing Company, New York.

Toulmin, S. E. (2003): The Uses of Argument Updated Edition. Cambridge University Press, Cambridge.

Toulmin, S. E., Rieke, R. D. \& Janik, A. (1984): An Introduction to Reasoning. Macmillan Publishing Company, New York.

\section{Abstract \\ An Appeal to Selfishness or Reasonableness? Case Analysis Using Toulmin's Model of Argument}

The paper deals with Toulmin's approach to an argument. The primary goal is to present this approach and to show its application on selected material. The key question is: What is interesting in Toulmin's approach today and what it can show when investigating arguments. There are two simple steps to accomplish the goals of this paper and to give an answer to the key question. In the first step, Toulmin's theory is discussed, especially regarding The Uses of Argument. In the second step, Toulmin's approach is applied to the selected material, Přemluv bábu (Convince your grandma, 2010). Attention is paid to the model of argumentation, domain dependence, logical types and types of argument. In conclusion, it is shown that Toulmin is still debated and theoretically exciting and that its application to the selected material can provide useful guidance for the evaluation, although regarding formal tools, this assessment may not be exact.

Key words: Toulmin, S. E., Toulmin Model of Argument, argument, logical type, Convince your grandma

Ondráček, T. (2018): „Apel na sobeckost nebo na rozumnost? Případová analýza s využitím Toulminova modelu argumentu." Filosofie dnes 10(2): 60-93. Dostupné z www.filosofiednes.ff.uhk.cz 